\title{
11 \\ Polio vaccination, political authority and the Nigerian state
}

\author{
Elisha P. Renne
}

So I told him [a soldier] that even if they are going to kill me, I will not allow the governor to enter my house ... I also said in the governor's presence that even if President Jonathan comes here, I will not allow them to immunize my child. So the governor held my hand that I should allow him to enter but I refused. I told him that this is not his house and so I will not allow him in. He pleaded with me to allow him in. He asks if I know him I said yes but I will not allow him to immunize my child. ${ }^{1}$

In an exchange between an elderly trader and the governor of Kaduna State in the Rigasa neighbourhood of Kaduna, in northern Nigeria, the trader-grandfather challenged the authority of his governor, and even his president, to immunise his granddaughter during a house-to-house polio vaccination exercise. This episode captures the contested nature of vaccination initiatives - between parents and the state, between individual freedom and societal benefits, between those with political authority and those resisting it. During the hour-long stand-off, which resembled something of a community drama performance with many neighbour-residents watching the proceedings, both sides - the governor and the grandfather - asserted their positions. Ultimately, the governor won, although it was not a voluntary defeat as the grandfather explained, 'When they threatened to use force against me, I threw the girl at them to immunize her. I gave them the girl. They only immunized her by force, not because I wanted.'

This incident suggests the particular social relationship between those with political authority and the legitimate power of the state to 
use force against those who resist them. Vaccination programmes provide a useful means by which to examine this relationship since they must be run on a national basis in order to obtain herd immunity approximately 80 per cent coverage - which prevents or reduces the spread of communicable diseases such as measles and poliomyelitis. ${ }^{3}$ Vaccination campaigns thus rely on the political authority and police power of the state to carry out public health programmes for the benefit of its citizens. The success of these programmes, in turn, may bolster the legitimacy of state control of its citizenry - through lower infant and child morbidity and mortality rates that increase its credibility - and foster a sense of national pride in a country's progress. Through vaccination programmes, government health officials also amass a range of vital statistics that track both individuals and disease - which relates to Foucault's notion of bio-power - as a means of controlling populations and strengthening the powers of the state. ${ }^{4}$ Indeed, the Kaduna State governor visited the Rigasa neighbourhood during the special round of the June 2013 sub-National Immunization Plus Days in Kaduna precisely because it had been identified as an area of parental noncompliance, based on data collected during earlier immunisation day exercises (Figure 11.1). Yet the specific historical context of vaccination programmes - how, by whom, and why they were implemented - and vaccine production and procurement has had consequences for such interventions and how they have been subsequently perceived.

In northern Nigeria, vaccination campaigns for smallpox and treatment camps for cerebrospinal meningitis were introduced by British health officials during the colonial period (1903-60) and vaccines used were generally imported from Great Britain. Following independence in October 1960, vaccination initiatives, such as the Smallpox Eradication Programme (SEP) and the Global Polio Eradication Initiative (GPEI), implemented by the Nigerian Ministry of Health and National Primary Health Care Development Agency (NPHCDA) with support from international NGOs, have been viewed with suspicion by some as postcolonial western interventions. In northern Nigeria, rather than legitimating state control of its citizens and promoting feelings of national pride by 'kicking polio out of Nigeria', the implementation of the GPEI has contributed to some Nigerians' resistance to state authority. While Nigerian government officials have insisted on pursuing the GPEI, some parents have resisted the programme's initial 


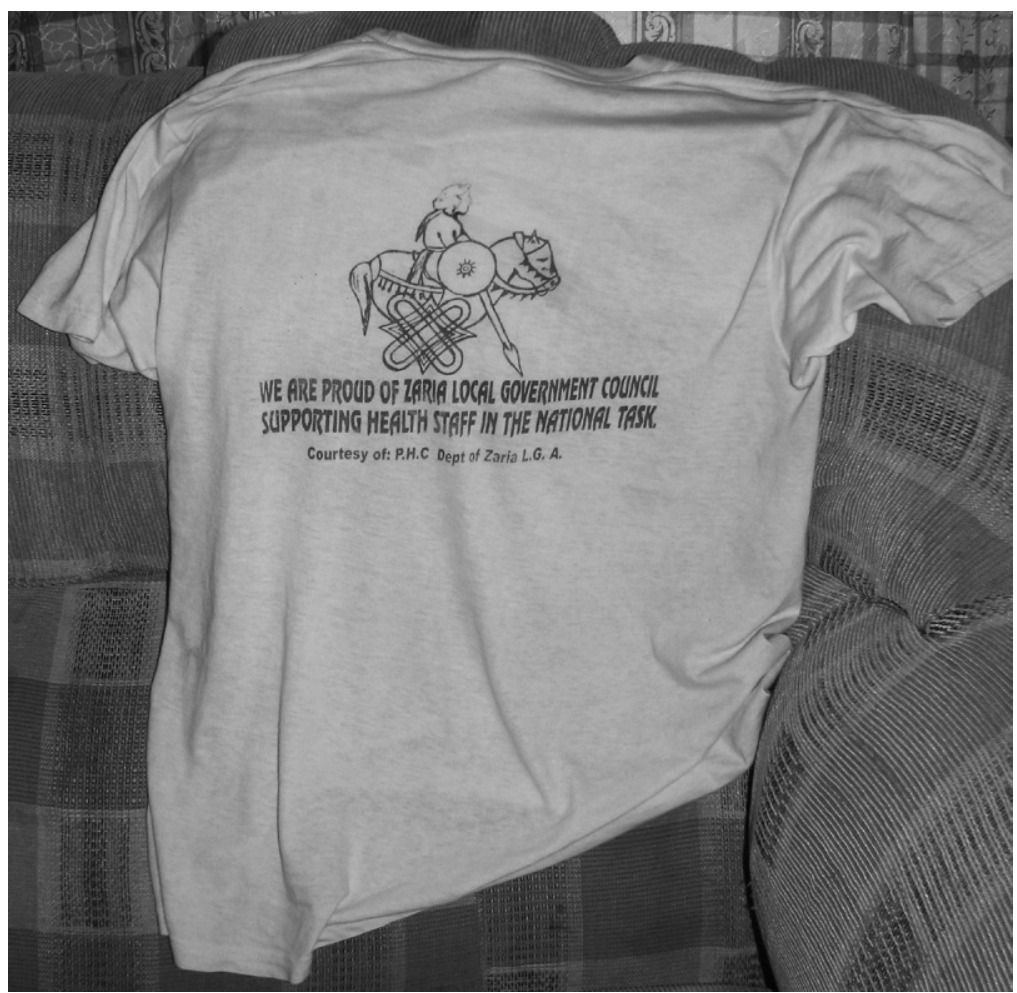

Figure 11.1 T-shirt produced for the polio vaccination team members.

single-minded concern with polio vaccination rather than on other childhood diseases, which they consider to be more life-threatening for their children. ${ }^{5}$ Vaccination programmes thus provide insights into the relationship between citizen resistance and state power, for as Greenough has noted: 'Public health measures derive their authority from the police powers of the state, and people do not lightly offer themselves (or their immune systems) to government even when its authority is legitimate. ${ }^{6}$ Furthermore, the Nigerian government's focus on the polio vaccination campaign highlights its failure to provide basic primary health care and consistent provision of viable vaccines, particularly in rural areas. ${ }^{7}$ Along with problems in the provision of other basic 
services such as clean water and electricity, these deficiencies have reinforced people's questions about the legitimacy of the Nigerian state and vaccination programmes promoted by its political leaders.

That GPEI implementation and purchases of imported oral polio vaccine (OPV) was funded by international organisations associated with the West (e.g., Rotary International, the European Union, the KfW Development Bank, the Gates Foundation, CDC, CIDA, UNICEF and WHO) has also led some Muslim parents, religious leaders and medical professionals in northern Nigeria to question the safety of the OPV on different grounds: fears that imported vaccines contained substances to reduce Muslim populations; beliefs that illness and cure are best addressed through prayer; and questions about the safety of vaccines, similar to concerns of some parents in the West. ${ }^{8}$ This resistance has, nonetheless, been countered by the power of the Nigerian state in various ways - through threats of parental arrest, local government monitoring, media censorship and harassment of vaccine critics. These actions have been tempered by various sorts of health incentives and community projects as well as by plans to establish a national programme of vaccine production. ${ }^{9}$ This particular configuration of resistance and power, which also includes many Nigerians' support for national efforts to end polio transmission in Nigeria, underscores the distinctive relationship between citizens and the state that the implementation of the GPEI in Nigeria in 1996 reveals.

This chapter begins with a discussion of the basis of state power - the political authority of officials of the Ministry of Health and related federal and INGO programmes - to carry out vaccination initiatives through immunisation campaigns, national house-to-house immunisation days, and routine immunisation provided at local clinics and hospitals.

The workings of these federal programmes are then related to the particular forms of resistance to them as expressed by parents, local political and religious leaders, university professors and, at times, by immunisation teams and clinic workers themselves. In 2013, more violent resistance to the GPEI - specifically, the murder of nine polio immunisation team members in Kano, Nigeria ${ }^{10}$ - has hampered vaccination efforts and has led to increased insecurity and aggressive government counter-measures. ${ }^{11}$ Continuing resistance, however, has also led to programmes and action meant to address resisters' complaints 
- through improved routine immunisation at renovated clinics, special programmes for bed net distribution and measles vaccination, improved health communication about polio, programmes providing monetary awards to state governors and foodstuffs to cooperating mothers as well as community improvements. Yet despite these measures, resistance to polio vaccination efforts has continued, particularly in northern Nigeria. The chapter concludes with an examination of the state of routine immunisation in 2015, which includes clinics with erratic vaccine supplies as well as plans for new immunisation initiatives and the use of inactivated polio vaccine (IPV) for the final stages of the GPEI. ${ }^{12}$ Despite the use of coercive, as well as appealing, measures in government's efforts to insure parents accept polio vaccination for their children, the state's ability to revitalise a national programme of primary health care, which includes the provision of early childhood vaccines, routine immunisation and basic health care for its citizens, will play an important part in the successful conclusion of the GPEI.

\section{Vaccination programmes in colonial and independent Nigeria: state power and health agendas}

In northern Nigeria, vaccination campaigns have been associated with the commencement of British colonial rule in 1903, when government officials had to address major and recurrent epidemics of smallpox and cerebrospinal meningitis on a shoestring budget. ${ }^{13}$ While British colonial officials introduced imported lanolinated calf lymph from the British Lister Institute for smallpox vaccination in 1921, there was resistance to vaccination in the North. This resistance, which reflected a fear of Europeans and their medicine and also possibly a preference for local inoculation practice by some, ${ }^{14}$ was compounded by the vast size of the Northern Province and inadequate health resources of the colonial medical service. This situation resulted in considerably fewer smallpox vaccinations being carried out in this area.

The colonial administration continued to try to improve immunisation levels, which included the introduction of a Vaccination Ordinance, originally enacted in 1917. In 1945, the Ordinance was amended to include a schedule for compulsory vaccination of adults and their children to be organised by local political authorities. These Native Authority officials (who would have been emirs and traditional chiefs) 
were also responsible for determining penalties for non-cooperation, although specific fines for non-compliance were subsequently introduced ${ }^{15}$ However, while colonial government officials could draft ordinances and determine fines on paper, which could be used to force traditional rulers to compel vaccination in their areas of jurisdiction, they had little means for enforcing their rules.

Along with smallpox vaccination, colonial officials also organised campaigns to treat those affected during outbreaks of cerebrospinal meningitis (CSM), which have occurred in northern Nigeria in five to ten year cycles, with recent major epidemics occurring in 1949-51, $1960-62,1970,1977$ and 1996. ${ }^{16}$

Until 1969 when an effective meningitis vaccine was developed, the colonial and later Nigerian government officials encouraged measures such as sleeping with open windows or out of doors to counter the disease. Shortly after independence a large isolation camp was set up in Kano during the 1960-62 epidemic, where patients were housed in tents and fed at government expense; treatment consisted of the use of imported sulfonamide drugs.

While the measures taken during smallpox and CSM outbreaks attempts at forced immunisation and quarantine or treatment at isolation camps - during the colonial period may have disinclined some to accept vaccination, others were sufficiently impressed with the benefits of western medicine to do so. Unlike smallpox and CSM, colonial medical officers were not concerned about poliomyelitis. Officials assumed that Nigerians had natural immunity. ${ }^{17}$ However, Familusi and Adesina, in a study of hospital records of Nigerian children brought to University College Hospital-Ibadan from 1964 to 1973 with paralysis symptoms associated with polio, argued that polio was prevalent throughout the year in Ibadan and its surrounding areas. ${ }^{18}$ After a shortlived polio vaccination programme in Ibadan using imported oral polio vaccine carried out by the World Health Organization (WHO) in 1974, the number of polio cases declined, leading Familusi and Adesina to advocate for routine vaccination for the disease. ${ }^{19}$

The smallpox and meningitis vaccines which were regularly administered by colonial government health personnel were generally imported. When an attempt was made in 1941 to manufacture smallpox vaccine in the colonial laboratory service in Yaba, Lagos, the heatsensitive lanolinated vaccine produced there lost its potency under 
unrefrigerated conditions. ${ }^{20}$ Although this vaccine continued to be produced and used by Nigerian government health staff during the Smallpox Eradication Programme, which commenced in Nigeria in 1967, the CDC recommended the use of imported freeze-dried vaccine provided by the WHO. ${ }^{21}$ While a freeze-dried vaccine that met international standards was eventually produced at the Federal Vaccine Production Laboratories at Yaba in $1974,{ }^{22}$ by the time that the Expanded Programme on Immunisation was fully implemented in Nigeria, vaccines for the programme were being imported by UNICEF. Unlike countries such as Hungary and Brazil discussed by Vargha and Benchimol (Chapters 3 and 7, this volume), there has not been a large and sustained national programme of vaccine production in Nigeria, although plans to begin such a programme were announced in $2012 .^{23}$

\section{The expanded programme on immunisation in Nigeria}

The Nigerian government took a different approach to national vaccination with the implementation of the Expanded Programme on Immunization (EPI), which began in Nigeria in 1979.

The goal of this horizontal health initiative, sponsored by WHO, was to provide vaccines for diphtheria, pertussis, tetanus, measles, polio and tuberculosis to more than 80 per cent of children worldwide through a system of primary health care centres. ${ }^{24}$ While this goal was attained in some countries, particularly those with well-developed health infrastructures and trained personnel, in Nigeria, infrastructural, political and economic problems hampered routine immunisation.

Indeed, immunisation levels for the early 1980s were low, ranging from 5 to 10 per cent. ${ }^{25}$ This situation was partly due to political and economic instability during the period 1979-86, when Nigerians elected a civilian president and subsequently experienced two military coups. However, during the military regime of General Ibrahim Babangida, who was anxious to gain international approval for his government, he appointed Professor Olikoye Ransome-Kuti as Minister of Health in 1986. Ransome-Kuti established a programme of primary health care centres throughout the country, with vaccines for the six early childhood diseases made widely available. ${ }^{26}$ In March 1988, the first phase of a national immunisation exercise was held at primary health care centres, which included the distribution of free vaccines; nonetheless, 
nationally only fifty per cent of children under two years of age were immunised. In 1989, Ransome-Kuti pledged to achieve eighty per cent coverage by December $1990,{ }^{27}$ in line with the UNICEF goal of Universal Child Immunization. In Nigeria, this goal was only achieved for Bacille-Calmette-Guérin vaccine (BCG) coverage. ${ }^{28}$

The year 1990 was considered to be the high-point in national immunisation coverage. However, on 30 June, responsibility for primary healthcare services was transferred to the local governments as part of a structural adjustment programme initiated by the International Monetary Fund, which required the federal government to curtail spending on social services; ${ }^{29}$ in 1991 , states were required to purchase their own vaccines. ${ }^{30}$ Since imported vaccines used during the EPI drive in 1990 had been provided by UNICEF and other non-governmental organisations via the federal government without charge to local governments, the availability of these vaccines drastically declined when federal responsibility for primary health-care services was transferred to local governments. Consequently, there was a breakdown in the provision of routine immunisation through primary health-care clinics and hospitals in local governments. Overall immunisation levels, as represented by diphtheria, pertussis and tetanus (DPT3) coverage, declined and by 1993, were reported to be around 30 per cent based on government data. ${ }^{31}$ This decline in immunisation levels, which included complete sequences of polio vaccination, may be seen in a comparison of data from the 1990, 1999 and 2003 Nigerian Demographic and Health Surveys. ${ }^{32}$

\section{The reorganisation of the EPI as the National Programme on Immunization (NPI)}

After a bloodless coup, led by General Sani Abacha in November 1993, government officials sought to revitalise the national immunisation programme. In July 1995, the Expanded Programme on Immunization (EPI) was renamed the National Programme on Immunization (NPI), in order to stress the nation's responsibility for immunisation and vaccine provision in Nigeria. ${ }^{33}$

In 1996, this programme was formally launched as part of the Family Support Programme, a project run by the First Lady, Miriam Abacha, although its staff worked closely with the Federal Ministry of Health and with international agencies and groups such as the WHO, UNICEF 
and Rotary International. One year after the NPI was launched, it came under the direction of Dr Dere Awosika, who continued in this position - under two successive presidents - until she was forced to resign in December 2005. Subsequently, the programme was merged with another federal parastatal, the NPHCDA, under the Ministry of Health, in 2007.

During its tenure, the NPI was responsible for the importation and distribution of vaccines to cold-store centres throughout the country. It was also responsible for promoting immunisation in Nigeria, including the provision of oral polio vaccine and the promotion of the GPEI.

\section{The GPEI and the Nigerian state}

With the decline in routine immunisation during the 1990s, NPI officials initiated a mass polio immunisation programme through the organisation of National Immunization Days when health workers went house to house, rather than relying on mothers to bring their children in for vaccination at poorly supplied clinics and hospitals. This entailed hiring and training vaccination team members as well as distributing cold chain equipment and vaccines, the latter obtained through UNICEF. ${ }^{34}$ They also needed to establish a system for monitoring the wild poliovirus through the identification of children with acute flaccid paralysis (paralysis in one or more limbs), which included the collection, transport and analysis of stool specimens. In 1996, a laboratory at University College Hospital, Ibadan, was accredited by the WHO for the analysis of stool samples of children with acute flaccid paralysis. ${ }^{35}$ Officials also implemented special programmes which included SubNational Immunization Days, when efforts were directed toward states and local governments where immunisation coverage was low and 'mop-up' days, when health workers focused on specific wards and neighbourhoods to improve vaccination levels. All children under the age of 5 were given oral polio vaccine (OPV), regardless of whether they had received earlier doses in order to ensure universal coverage, since cards recording vaccination histories were not used. When the initial goal of global polio eradication by the end of year 2000 was not met, WHO officials extended the Polio Eradication Initiative goal to $2005 .{ }^{36}$ 
In northern Nigeria, these efforts were hampered by the decision of the Governor of Kano State, Alhaji Ibrahim Shekarau, to cancel National Immunization Days in Kano in October 2003. With increasing suspicions about the safety of the polio vaccine, the Federal Ministry of Health organised a health team which went to test the vaccine in South Africa. ${ }^{37}$ At the same time, the Jama'atu Nasril Islam (JNI), the umbrella organisation for Muslims in Nigeria, sent a team of their own experts to test the vaccine in Indian laboratories. On 23 December 2003, the Minister of Health, Professor Eyitayo Lambo, announced that the 'Oral Polio Vaccine (OPV) used in Nigeria for immunisation, 'had been found to be safe and free of anti-fertility agents and HIV.38 One month later, the JNI team, which included two professors from Ahmadu Bello University, officially announced that they found the OPV vaccine to be contaminated. $^{39}$

However, after additional tests were jointly carried out by $\mathrm{MOH}$ and JNI experts, ${ }^{40}$ the Sultan of Sokoto, Alhaji Muhammadu Maccido, announced on 17 March 2004 that the 'Oral Polio Vaccine is safe. ${ }^{41}$ Nonetheless, Governor Shekarau, continued to refuse the use of the WHO-procured vaccines. ${ }^{42}$ While the former President Ibrahim Babangida suggested that the Nigerian drug companies produce their own polio vaccine, ${ }^{43}$ this option was not considered to be practical at the time. In July 2004, Governor Shekarau changed his position and vaccination resumed in Kano State, with health workers using polio vaccine manufactured in Indonesia. ${ }^{44}$

Yet even after the Kano State polio vaccination boycott was resolved, house-to-house polio immunisation continued with lacklustre results until January 2006 when the newly appointed acting director of the NPI, Dr Edugie Abebe, implemented a programme called Immunization Plus Days. ${ }^{45}$ This programme provided parents with a range of health incentives, which included bed nets, measles vaccination and deworming tablets. The popularity of this programme contributed to a decline in the number of confirmed cases of wild poliovirus, from 1,122 cases in 2006 to 285 cases in 2007. However, political considerations again intervened and when the NPI was merged with the National Primary Health Care Development Agency (NPHCDA) in 2007, Dr Abebe resigned. The NPHCDA director, a political appointee, who took over the polio immunisation programme was inexperienced; funds ran out for bed nets and once again there was an increase in cases. 
By the end of November 2008, Nigeria had 758 confirmed cases, the most cases of wild poliovirus in the world. ${ }^{46}$

Yet political decisions made at the end of 2008 also contributed to a significant improvement of polio vaccination efforts in Nigeria the following year. In October 2008, Dr Muhammad Ali Pate, was appointed as the new NPHCDA executive director. Not only was Dr Pate an experienced health official who had worked with the World Bank, he was also a northerner who was sympathetic to the concerns of northern Nigerian parents. ${ }^{47}$ His organisational leadership also contributed to increased use of health incentives and new distribution methods, such as the use 'of 'transit teams' to vaccinate children on public and private transport, and the use of 'street teams' to cover children in playgrounds and other areas outside the household. ${ }^{48}$ While focusing on polio, health officials emphasised community communication and improvements in primary health care provision.

This change in perspective was paralleled by the Expert Review Committee's conclusion that: 'The growing national and state level commitment to polio eradication and immunisation must be taken down to local government and community level. ${ }^{49}$ Improved immunisation efforts in 2009 contributed to a significant decline in confirmed cases of wild poliovirus, with only twenty-one cases by the end of 2010 . Although these numbers increased in 2011-13, they declined significantly in 2014 (Table 11.1).

\section{Other factors contributing to the 2010 decline}

While this significant decline in number of polio cases reflected greater levels of immunity among more Nigerian children due to changes in programme leadership and vaccination campaigns, there were other factors - social, medical, institutional, technical and legal - that contributed to an increasing number of parents who agreed to have their children vaccinated in northern Nigeria.

In June 2009, Alhaji Muhammad Sa'ad Abubakar, the Sultan of Sokoto, organised a committee of fourteen northern Nigerian traditional rulers to address the continued presence of polio in the North. ${ }^{50}$ While his predecessor, Alhaji Muhammadu Maccido, had also supported the campaign, the new sultan's relative youth and conviction that northern Nigerians should not be seen as 'backward' energised his 
Table 11.1 Cases of acute flaccid paralysis (AFP) and confirmed cases of wild poliovirus and circulating vaccine-derived poliovirus, Nigeria, 1999-2015 (as of 28 October 2015)

\begin{tabular}{lrcc}
\hline Year & $\begin{array}{c}\text { Total confirmed } \\
\text { polio cases }\end{array}$ & $\begin{array}{c}\text { Wild-virus } \\
\text { confirmed polio } \\
\text { cases }\end{array}$ & $\begin{array}{c}\text { Vaccine-derived } \\
\text { confirmed polio } \\
\text { cases }\end{array}$ \\
\hline 1999 & 981 & 98 & - \\
2000 & 638 & 28 & - \\
2001 & 56 & 56 & - \\
2002 & 202 & 202 & - \\
2003 & 355 & 355 & - \\
2004 & 782 & 782 & - \\
2005 & 831 & 830 & 22 \\
2006 & 1144 & 1122 & 71 \\
2007 & 356 & 285 & 66 \\
2008 & 864 & 798 & 154 \\
2009 & 542 & 388 & 27 \\
2010 & 48 & 21 & 34 \\
2011 & 96 & 62 & 8 \\
2012 & 130 & 122 & 4 \\
2013 & 57 & 53 & 30 \\
2014 & 36 & 6 & 1 \\
2015 & 1 & 0 & \\
\hline & & & \\
\hline
\end{tabular}

Source: CDC, Global Polio Eradication website, www.polioeradication.org/ Dataandmonitoring/Poliothisweek.aspx (accessed 29 October 2015)

efforts to get traditional rulers as well as religious leaders involved. His leadership contributed to an increased acceptance of the polio eradication initiative by those who had rejected it before.

In November/December 2008, polio vaccines were given in conjunction with a national integrated measles campaign, which reflected a shift in emphasis from polio to measles. Since many northern Nigerian parents considered measles to be a greater risk to their children, this change demonstrated an acknowledgement of local concerns. Also, a more organised system for bed net distribution, developed in 2010, reflected an appreciation of parents' anxiety over malaria. Mothers who had brought their children for polio immunisation received a slip that 
entitled them to two bed nets, which were distributed at local sites by health officials. The popularity of bed nets contributed to increased immunisation as well. In addition to organising traditional and religious leaders and improving the distribution of health incentives, state ministers of education were encouraged to implement immunisation requirements for children attending nursery and primary schools. In Kaduna State in May 2009, for example, a letter went out to all school principals, noting that children under the age of 5 needed to to be immunised when immunisation personnel visited their schools. While some parents objected to this programme, they were allowed to write letters requesting that their children not be immunised. This effort to incorporate immunisation records as a requirement for school attendance is part of a larger process of routinising immunisation in Nigeria. ${ }^{51}$ By the end of 2010, the decline in confirmed cases of wild poliovirus was matched by improved overall levels of immunisation. However, political events in northern Nigeria in subsequent years confounded these numbers.

\section{Vaccination as a node of resistance to state power}

Earlier examples of resistance to vaccination campaigns during the colonial period in northern Nigeria have continued in the independence era. The particular form that this resistance has taken reflects changing political and economic circumstances in which the GPEI has been implemented. As Taylor notes, 'the balance of power between state and population, contemporary to polio, has shifted dramatically', after 2009. ${ }^{52}$

During the early years of the twenty-first century, the GPEI has continued to face various forms of covert resistance to the campaign, which include parents misleading immunisation teams about children residing in houses, hiding children, and deceptively marking houses and children's fingers. However, in some communities, parents have become more overt in their resistance, with some demanding that polio workers provide basic amenities to their communities such as boreholes before allowing vaccination teams to proceed. ${ }^{53}$ Indeed, parents' dissatisfaction with the failure of the federal and state governments to provide primary health care has contributed to continued resistance to the polio campaign, exemplified by an incident described in November 2011: 
The only dispensary at the village [in Kano State] has been under lock and key for years, with no medical personnel attending to the health needs of the community ... All attempts to get local or state government to put the structure to use for the benefit of the community have proved abortive, residents said ... [Despite] the seeming unconcern about their health needs nonetheless, government keeps posting vaccinators with the objective of eradicating polio, whom the residents consistently [reject]. They said their rejection was in a bid to subvert the initiative so that by government failing in the cause, they will ... exact a payback for the suffered neglect. ${ }^{54}$

A lack of interest in polio as a public health concern, along with government officials' inability to reconstitute a working primary health-care programme, have undermined government's credibility among some northern Nigerians. Others, like the grandfather-trader in RigasaKaduna, have openly refused to have their children vaccinated under any circumstances and some have threatened violence against health workers who sought to enter their houses. Some say that the vaccine is contaminated with contraceptives or HIV. ${ }^{55}$ Similarly, two university professors from Ahmadu Bello University-Zaria, have questioned the safety of the oral polio vaccine in several nationally circulated DVDs in which they argue that western health specialists should not determine Nigerian health care priorities (Figure 11.2). They also expand on their long-standing views that OPV and other vaccines are unsafe and that some children are adversely affected by vaccination, reflecting arguments made by vaccine opponents in the West. ${ }^{56}$ Additionally, they question the legality of threats against parents who refuse vaccination of their children. ${ }^{57}$

Furthermore, while some Muslim teachers (malamai) have accepted vaccination of students in their schools, many are still opposed to vaccination as they suspect that there is 'something in the vaccine'. As one malam explained, 'I am doing something for the children - prayers - so that they don't need the OPV. ${ }^{58}$

Other religious scholars are opposed to vaccination on the grounds that Islamic medicines and medical practices obviate the need for use western medicine. These scholars have supported their position, citing the influential volume, The Prophetic Medicine. ${ }^{59}$ Indeed, Mohammad Yusuf, the late leader of the radical Islamic reform group, Jama'atu Ahlus-Sunnah Lidda'Awati Wal Jihad (JASLWJ), popularly known as 


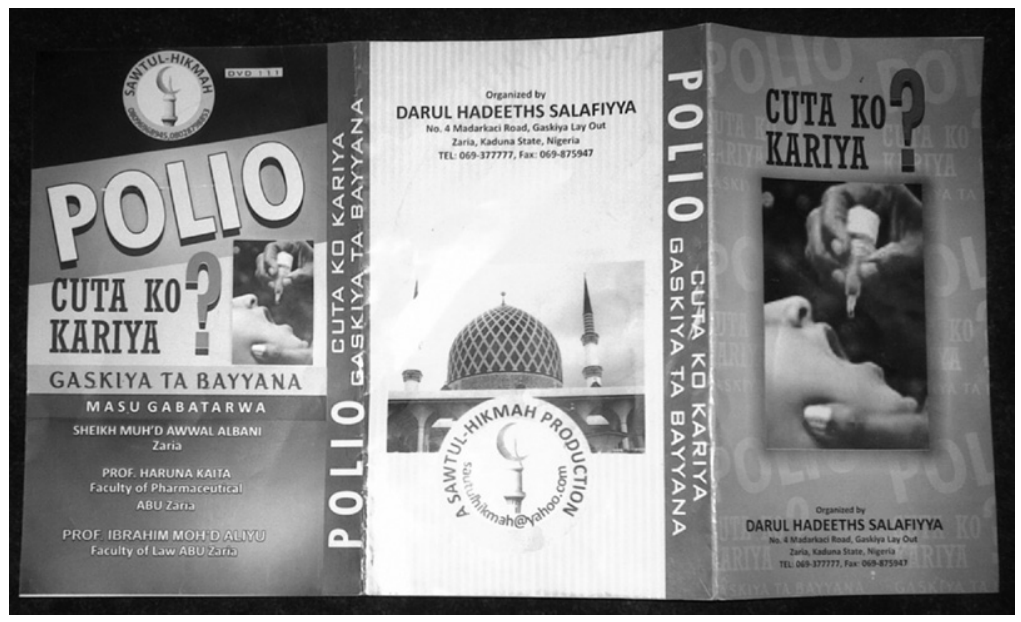

Figure 11.2 Cover of DVD, Polio: Cuta ko Kariya?

Boko Haram (literally, western education is forbidden), relied on The Prophetic Medicine, which is reflected in his assessment of western medicine and vaccines:

For Yusuf modern vaccines are not better than Prophetic medicine ... He also stated that he had read on the Internet that modern vaccines have side effects; hence prophetic medicine is better than modern vaccines. Here Yusuf seems to be echoing the rejection of polio vaccination by some Muslims. ${ }^{60}$

Yusuf's views on modern vaccines as harām (forbidden) have apparently influenced his followers in Borno and Yobe States, where low levels of immunisation in 2012 - 71 per cent and 65 per cent of children, respectively, have received no vaccinations ${ }^{61}$ - have contributed to continued poliovirus transmission in these two states.

However, with the escalation of political violence, particularly in Borno State, associated with Boko Haram and the extrajudicial killing of Yusuf in July 2009, ${ }^{62}$ government officials and police/military officers became the targets of Boko Haram members, not only in northeastern Nigeria but in other parts of the North as well. In February 2013, nine women health workers, who were preparing to go out for 
polio vaccine rounds in and near the metropolis of Kano, were shot and killed, although no group has claimed responsibility for the attack.

\section{Government responses: sticks and carrots}

Although some have associated the attack on the polio health workers in Kano with Boko Haram violence, ${ }^{63}$ Nigerian government officials specifically blamed the killings on those involved in a programme critical of the polio campaign aired on Wazobia, a popular Kano radio station. Two radio journalists, along with the station owner, were arraigned and appeared in court in February 2013:

The court was told that Rabo had on February 4, refused to allow polio officials to immunize his children, and that when the district head of Tarauni Local Government went to find out his reasons the following day, he conspired with the two journalists who aired a local programme called 'Sandar Girma' [literally, big stick; policemen are referred to as 'dan Sanda in Hausa]. The prosecutor added that on the programme, the duo 'discredited the polio immunization programme, defamed the character, reputation and personality of the district head in addition to instigating the attack on the polio officials. ${ }^{34}$

Following the trial, the station's broadcasting licence was suspended and the station was shut down. ${ }^{65}$

While GPEI officials have vowed to continue their efforts and immunisation teams have been accompanied by police escorts, the insecurity associated with Boko Haram's anti-government activities and subsequent military police counter-measures have hampered house-to-house vaccination efforts. The difficulties that this situation poses for vaccination efforts in northeastern Nigeria were noted in the May 2013 Independent Monitoring Board (IMB) report on polio eradication:

Insecurity in Nigeria is most challenging in the North East States of Borno and Yobe. These two states currently account for $69 \%$ of wild polio cases in Nigeria (and hence at the time of our meeting in the entire continent of Africa) in 2013. Population immunity has steadily declined. In Yobe, a quarter of non-polio AFP cases in quarter four of $2012 \mathrm{had}$ received zero doses of polio vaccine. In Borno, over 335,000 children (32\% of the target population) were missed during the April 2013 campaign. $^{66}$ 
In May 2013, President Goodluck Jonathan announced that a state of emergency had been imposed on three northeastern states - Borno, Yobe and Adamawa, ${ }^{67}$ two of which were named in the IMB report.

Aside from implementing a state of emergency and closing down radio stations that broadcast shows critical of the polio vaccination campaign, critics of the GPEI have also been threatened with arrest. In some communities with low levels of immunisation where parents have continued to resist the polio initiative, more drastic measures have been implemented in some local governments. In Kano, Kwara and Niger States, parents may be arrested for failure to vaccinate their children. ${ }^{68}$ In Gombe State, the governor announced at a primary health-care event in 2009 that 'his administration is looking into the possibility of enacting a law that would empower government to prosecute parents who do not allow their children to be immunized against the six child killer diseases. ${ }^{69}$ In Jamaa Local Government Area of Kaduna State, parents who do not allow their children to be vaccinated will face legal action:

Chairman of the local government, Mr Daniel Amos, gave the warning in Gidan Waya, while flagging off six-round of the immunization. He said the immunization of children against all child-killer diseases, particularly polio is compulsory. 'There is no justification for any parent to deny children this right, especially as polio immunization is administered free. Parents should play their roles properly and avail their wards for immunization. ${ }^{70}$

This pressure on local government chairmen to discipline parents and to support polio vaccination efforts has resulted in state officials such as 'the Kaduna State deputy governor, Ambassador Nuhu Audu Bajoga ... lead[ing] the search into some huts in southern Kaduna to find the children and have them immunized. ${ }^{71}$ It has also led to statements such as that made by the Chairman of Zangon-Kataf Local Government, Christopher Haruna, who 'pledged the council's readiness to continually lend support to government on polio issues by organising the people to regularly avail their children for vaccination. ${ }^{72}$ The strategy to shame and to put pressure on local government officials was also advocated in the May 2013 IMB Report:

A list of poor performing LGAs is on display in the Abuja Emergency Operations Centre. We commend the Programme for focusing their efforts on these disappointing LGAs. The LGA Chairmen responsible 
should continue to receive weekly, if not daily, telephone calls from the State and Federal level. ${ }^{73}$

Indeed, local government chairmen in states such as Borno and Yobe are in particularly difficult positions, as they are targets both of Ministry of Health officials and anti-government Boko Haram members.

Aside from pressure on local government leaders and parents, in some areas, parental permission is circumvented altogether through the mass immunisation of children on public transport vehicles ('transport teams') or in public areas where they congregate ('street teams') - using biscuits and candy as incentives, as one vaccination team leader in Kaduna State described: ${ }^{74}$

Now another strategy we have - we have a team who just immunizes children in the street. We find an elderly woman within the community, maybe she was a TBA for a long time so no one would shout at that woman if she gave OPV to the children. We used biscuits there, immediately after vaccinating she would give a biscuit to the child. That child will bring more children, without consulting the mother; they will just come. ${ }^{75}$

More recently, these coercive actions have been tempered by various sorts of incentives and community projects. Ministry of Health and GPEI officials have instituted other methods for addressing other, more indirect, forms of resistance. For example, in 'high-risk areas' with large numbers of 'non-compliant parents', GPEI programme officials sought to improve communications with these parents through presentations of educational films (magaji) ${ }^{76}$ and through FOMWAN (Federation of Muslim Women of Nigeria) participation on immunisation teams. These efforts have also included community rallies and the solicitation of support from Muslim teachers, religious leaders and governors. Health officials organised a meeting at the offices of the Jamatu Nasril Islam in Kaduna to encourage Muslim clerics in northern Kaduna State to advise their followers to vaccinate their children for polio. ${ }^{77}$ In 2013, the Gates Foundation began a programme that rewards governors of states with significantly reduced polio transmission and increased immunisation levels with substantial monetary awards. ${ }^{78}$ In June 2013, the Nigerian industrialist Aliko Dangote announced a plan to provide cooperating mothers with his products - sugar, salt and macaroni. ${ }^{79}$

Yet while such methods - both sticks and carrots - may work in the short term, the long-term solution to increasing levels of polio, as well 
as measles, BCG, DPT and yellow fever immunisation among children requires a working primary health-care system with functioning immunisation programmes. The inability of the Nigerian government to provide such a system has undermined attempts to attain sufficient levels of immunisation that would end the transmission of wild poliovirus and reduce measles cases in the country. Indeed, as one virology professor working with the GPEI observed, 'The progress they have made so far has been because of routine immunisation, not because of mass immunisation for polio. ${ }^{80}$

\section{Overall immunity and continuing problems with routine vaccination}

Thus the principal problem for GPEI officials has been the dysfunctional primary health-care system, particularly in rural areas in northern Nigeria where private health clinic services are not available. ${ }^{81}$ In some rural communities, local clinics are closed or lack personnel or provisions. ${ }^{82}$ When parents take their children for vaccinations, they may find 'stock-outs' and are forced to return. ${ }^{83}$ Furthermore, the irregular supply of electricity makes it difficult to maintain regular supplies of viable vaccines, while impoverished parents who want basic health care available free of charge are expected to pay for each vaccination received at clinics. ${ }^{84}$ This situation is particularly problematic in rural areas as one journalist investigating primary health-care provision discovered:

The correspondent, who had to disguise as a parent in search of a centre to obtain vaccination for herself and her baby, got the shock of her life when she visited a primary health centre in Ogbondoroko, a village in the outskirts of Ilorin, the Kwara State capital $\ldots{ }^{85}$ When our correspondent asked if she could get her baby immunised at the centre, the nurse on duty simply told her that she would have to wait for another month, as the clinic had just finished a round of immunisation exercise.

'You should have come last Friday. We do it once every month. That is the only time you will get it here. There is no consistent power supply here. So, we cannot afford to keep the vaccines in the proper condition for long; that is why you won't get it on any other day, the nurse said casually. Asked what measures were being taken to ensure that babies born before the earmarked day were vaccinated, one of the health workers ... said those who could not wait had to take their babies to health centres in neighbouring villages. ${ }^{86}$ 
Similar stories are reported from other parts of the country in national newspapers as well as in government documents such as a 2009 Expert Review Committee report on polio and routine immunisation:

The ERC notes some progress in improving data quality for routine immunization but again emphasizes that there is still a massive amount of work to be done to put routine immunization [RI] on a firm footing in Nigeria. It is frustrating that basic RI activities recommended in several previous meetings have not been carried out effectively. The ERC is forced to make the same recommendations again, and urges state and local governments to make the effort to deliver this basic service. ${ }^{87}$

These comments were echoed three years later in the 2012 twentyfourth ERC report which noted that, 'National efforts to strengthen routine immunization must be accelerated, with the finalization of a national immunization strategy and its endorsement by the InterAgency Coordinating Committee by end-2012.88

Similar challenges to routine immunisation were observed in the 2011 Annual Progress Report submitted to the Global Alliance Vaccine and Immunisation (GAVI) Secretariat by the Government of Nigeria on 25 May 2012:

The main challenges in the routine immunisation programme include some vaccines and injection supplies stock outs, repeated health workers' industrial strike actions and security challenges in several Northern States. The vaccine stock-out was due to the late release of the funds for RI (in July) and reallocation of RI vaccine funds to other priorities (measles and polio campaigns). ${ }^{89}$

Professor Oyewale Tomori, who has served on several polio Expert Review Committees and who is currently President of the Nigerian Academy of Science, noted that the irregular supply of vaccine, poor handling (e.g., lack of refrigeration) and inadequate supplies of syringes all contributed to declining levels of immunisation. ${ }^{90}$

In 2012, in order to address these concerns, President Jonathan established the 'Saving One Million Lives Initiative' programme, part of a plan to improve primary health care in Nigeria. Following his announcement, GAVI Alliance officials revealed in 2013 that they had 'approved US\$21 million (N3bn) to help improve vaccine supply chains in Nigeria as part of a partnership aimed at scaling up routine immunisation. ${ }^{91}$ Yet some health professionals, such as Dr Olarenwaju 
Ekunjimi, the President of the Association of Resident Doctors at the Lagos University Teaching Hospital, are sceptical that such large sums of money will not be usurped by those with access to donor funds. ${ }^{92}$ The firing in October 2013 of 'dozens of officials handling polio immunization in Kano State ... because they were using the exercise as a 'money-making venture' by the Kano State Governor, Rabiu Musa Kwankwaso, ${ }^{93}$ suggests that Dr Ekunjimi may be correct.

This connection between immunisation, politics and corruption is also suggested by one reader, whose comments followed a brief account of the NPHCDA Executive Director's plans to improve immunisation in northern Nigeria. ${ }^{94} \mathrm{He}$ wrote: 'Kindly immunise us against the following killer agents: 1 . Ebola Jonanthan $[s i c],{ }^{95}$ 2. Politicians, 3. JTF [Joint Task Force - the military-police force assigned to counter Boko Haram attacks], 4. Corruption, and 5. BOKO'. Professor Tomori voiced somewhat similar sentiments (more politely) when he 'stated that Nigerian leaders had only been paying lip service to issues of health - a situation that, he noted, was responsible for the "mediocre performance" in health care delivery and a near absence of accountability in national programmes of government for her citizens. ${ }^{96}$

\section{Conclusion}

Vaccination campaigns ultimately rely on the power of the state but they are facilitated by trust and citizens' belief that their government is helping them. ${ }^{97}$ When this sense of political responsibility and visible evidence of improvements in their lives - working health clinics, clean water and electricity - are lacking, some citizens may resist government vaccination programmes, particularly when they focus on a single disease such as polio, which is not viewed by parents as a major health concern.

When the Nigerian government implemented health programmes that had widespread parental approval (e.g., the Immunization Plus Program in 2006 and the Measles Immunization Campaign in 2008), immunisation levels increased in subsequent years, while confirmed cases of wild poliovirus declined. In this instance, northern Nigerian parents' support for the national task of raising levels of immunisation (and ending polio transmission) coincided with the hopes of Nigerian medical professionals for better vaccine provision and the 
possibility of national vaccine production as recently proposed. Yet in northern Nigeria, many residents' experience of government vaccination programmes differs from that of medical professionals and government officials. Some government vaccination programmes particularly the Expanded Programme on Immunisation and Immunization Plus Days that offered a range of health incentives - have improved Nigerians' acceptance of polio vaccination and have contributed to an interruption in transmission of wild poliovirus in Nigeria, announced by WHO in September 2015. ${ }^{98}$ Yet the government's inability to maintain consistent supplies of viable vaccines and of its failure to supply related basic services such as electricity and clean water, continue to undermine the political authority of the state in matters of health.

Thus an association of vaccination programmes in the West with citizens' experience of bio-power whereby they incorporate state objectives through health regimes of the body, which strengthen the power and oversight of the state contrasts with the experiences of many northern Nigerians, reflecting a distinctive historical context, particularly biomedicine's association with British colonial rule. ${ }^{99}$ Indeed, the vaccination campaigns in northern Nigeria display a certain historical consistency in their top-down approach to public health, ${ }^{100}$ their use of imported vaccines and the implementation of laws which hold local government officials and traditional rulers responsible for the success of vaccination initiatives. These initiatives simultaneously foster forms of resistance - such as hiding children or parents 'voting with their feet', while revealing the weakness of state in enforcing vaccination laws, providing vaccines and maintaining oversight over the running of immunisation programmes. Nonetheless, as Abu-Lughod notes, romanticising resistance to state power can be misleading, ${ }^{101}$ as the coercive measures used in the implementation of the GPEI in recent years suggest. Such vaccination programmes can - in the short term - reduce and end wild poliovirus transmission and reinforce political authority of the state through the implementation of police powers. Yet many Nigerian health professionals believe that parents' long-term acceptance of vaccination is contingent on a viable national primary health-care system, which provides routine immunisation as well as evidence of their government's concern for their well-being, on which high levels of immunity in Nigeria ultimately rest. 


\section{Notes}

1 I. Mudashir, 'Polio: Drama as Trader Turns Back Gov Yero', Weekly Trust (22 June 2013), www.weeklytrust.com.ng (accessed 22 June 2013).

2 Ibid.

3 E. Parry, R. Godfrey, D. Mabey and G. Gill (eds), Principles of Medicine in Africa (Cambridge: Cambridge University Press, 2004), p. 139.

4 M. Foucault, The History of Sexuality, Vol. 1: An Introduction (New York: Random House, 1978), p. 139.

5 L. Abu-Lughod, 'Romance of Resistance', American Ethnologist, 17:1 (1990), pp. 41-55.

6 P. Greenough, 'Intimidation, Coercion, and Resistance in the Final Stages of the Smallpox Eradication Campaign in Southeast Asia, 1973-1975, Social Science \& Medicine, 41:5 (1995), p. 633.

7 B. Adebayo, 'Vaccine Delivery, Still a Mirage in Nigeria', Punch (23 March 2013), www.medicalworldnigeria.com (accessed 16 August 2013).

8 S. Blume, 'Anti-Vaccination Movements and Their Interpretations', Social Science \& Medicine, 62:3 (2006), pp. 628-42.

9 C. Obinna, 'Nigeria to Begin Vaccine Production - NAFDAC', The Vanguard (27 March 2013), www.vanguardngr.com/2013/03/nigeria-tobegin-vaccine-production-nafdac/ (accessed 1 February 2014).

10 L. Adamu and H. Yaya, '10 Polio Workers Shot Dead in Kano: ... It's an Act of Cowardice - Pate ... We're Trailing the Gunmen -IG', Daily Trust (9 February 2013), www.dailytrust.com.ng (accessed 9 February 2013).

11 Amnesty International, Nigeria: Trapped in the Cycle of Violence (London: Amnesty International, 2012).

12 Adebayo, 'Vaccine Delivery, Still a Mirage in Nigeria'; R. Leo, 'GAVI Gives N3bn to Improve Vaccine Access', Daily Trust (13 August 2013), www.dailytrust.com.ng (accessed 13 August 2013).

13 By 1908, 'there were sixty-three medical officers in Nigeria in government service, although the primary concern of these doctors was maintaining the health of the expatriate population; R. Schram, A History of the Nigerian Health Services (Ibadan: University of Ibadan Press, 1971), p. 141.

14 E. Herbert, 'Smallpox Inoculation in Africa', Journal of African History, $16: 4$ (1975), p. 546.

15 F. Jakeway, 'An Ordinance to Amend the Vaccination Ordinance', Nigerian Gazette (No. 16 of 1945), pp. 273-5.

16 The earliest recorded outbreak of cerebrospinal meningitis in Nigeria occurred in 1906 in Sokoto; see C. Ejembi, E. Renne and H. Adamu, 'The Politics of the 1996 Cerebrospinal Meningitis Epidemic in Nigeria', Africa, 68:1 (1998), pp. 118-34. 
17 E. Renne, The Politics of Polio in Northern Nigeria (Bloomington: Indiana University Press, 2010), p. 25.

18 W. R. Collis, O. Ransome-Kuti, M. E. Taylor and L. E. Baker, 'Poliomyelitis in Nigeria', West African Medical Journal, 10:1 (1961), pp. 217-22.

19 J. B. Familusi, J. B. and V. A. O. Adesina, 'Poliomyelitis in Nigeria: Epidemiological Pattern of the Disease among Ibadan Children', Journal of Tropical Paediatrics and Environmental Child Health, 23:3 (1977), pp. $120-4$.

20 D. W. Horn, 'The Epidemic of Cerebrospinal Fever in the Northern Provinces of Nigeria, 1949-1950', Journal of the Royal Sanitation Institute, 71:5 (1951), pp. 573-88; F. Fenner, D. A. Henderson, I. Arita, Z. Jezek and I. D. Ladnyi, Smallpox and Its Eradication (Geneva: WHO, 1988), p. 862.

21 Fenner et al., Smallpox and Its Eradication, p. 883.

22 However, both the $\mathrm{CDC}$ and $\mathrm{WHO}$ also sought to improve vaccine production at the Yaba laboratory and a WHO vaccine production expert, along with Nigerian laboratory staff trained in the UK, worked to produce a viable freeze-dried vaccine in 1974; Ibid., p. 885.

23 An agreement by the federal government and May \& Baker Nigeria PLC proposed that vaccine production begin by 2014 (S. Ogundipe, 'Nigeria: FG Domesticates Vaccine Production', The Vanguard (26 June 2012), http://allafrica.com/stories/201206260182.html (accessed 1 February 2014).

24 E. Ekanem, 'A 10-year Review of Morbidity From Childhood Preventable Diseases in Nigeria: How Successful is the Expanded Programme of Immunization (EPI)?', Journal of Tropical Pediatrics, 34:6 (1988), pp. 323-8.

25 Federal Ministry of Health, Nigeria, Expanded Program on Immunization: The National Coverage Survey, Preliminary Report (Lagos: Federal Ministry of Health, 1991), p. 3.

26 O. Olatimehin, 'Accomplishing the Goal of EPI', National Concord (27 April 1988), p. 3.

27 O. Orere, 'Minister Pledges to Meet Immunisation Target Next Year', Guardian (13 December 1989), p. 20.

28 National Planning Commission [NPC-Nigeria] \& UNICEF, Children's and Women's Rights in Nigeria: A Wake-Up Call: Situation Assessment and Analysis 2001 (Abuja: National Planning Commission and UNICEFNigeria, 2001), p. 84.

29 Anonymous, 'Editorial: Structural Adjustment and Health in Africa', The Lancet, 335:8694 (1990), pp. 885-6.

30 A. Umar, 'No Free EPI Vaccines to States from '90', New Nigerian (27 October 1989), p. 24. 
31 Feilden Battersby Analysts (FBA), The State of Routine Immunization Services in Nigeria and Reasons for Current Problems (Bath: FBA Health Systems Analysts, 2005), p. 3, www.technet21.org/backgrounddocs.html (accessed 15 August 2005).

32 S. Bonu, M. Rani and O. Razum, 'Global Public Health Mandates in a Diverse World: The Polio Eradication Initiative and the Expanded Programme on Immunization in Sub-Saharan Africa and South Asia', Health Policy, 70:3 (2004), p. 333.

33 O. Alabi, 'Expansion on Immunisation', Daily Sketch (22 June 1995).

34 World Bank, 'Project Paper on a Proposed Additional Financing: Partnerships for Polio Eradication Project, Report No. 44776-NG' (Abuja: World Bank, Africa Region Office, 2008), www-wds.worldbank.org (accessed 1 November 2008).

35 This in-country testing of stool samples facilitated the rapid identification of areas with wild poliovirus cases. Samples with genomic sequencing that suggest the possibility of circulating vaccine-derived polio virus are sent to the CDC in Atlanta (Interview: Professor Festus Adu, University College Hospital, 22 February 2008, Ibadan).

36 World Health Organization, Global Polio Eradication Initiative, Strategic Plan 2001-2005 (Geneva: WHO, 2000).

37 G. Muhammad, 'The Debate Goes On', Weekly Trust (13-19 December 2003), pp. 1-2.

38 I. Okpani, 'FG Declares Polio Vaccine Safe', Daily Trust (24 December 2003), pp. 1-2.

39 S. Babadoko and M. Kazaure, 'Polio Vaccine Contaminated-JNI Reports', Daily Trust (26 January 2004), pp. 1-2.

40 Okpani, 'FG Declares Polio Vaccine Safe'.

41 Anonymous, 'Oral Polio Vaccine is Safe - Sultan of Sokoto', Daily Trust (22 March 2004), p. 10.

42 M. Kazaure, 'Kano Rejects FG, JNI Reports', Weekly Trust (18 March 2004), pp. 1-2; I. Ghinai, C. Willott, I. Dadari and H. Larson, 'Listening to the Rumours: What the Northern Nigeria Polio Vaccine Boycott Can Tell Us Ten Years On', Global Public Health, 8:10 (2013), pp. $1138-50$.

43 K. Sule, 'Polio Vaccine: IBB tasks Nigerian Drug Coys', Daily Trust (25 March 2004).

44 Anonymous, 'Kano Imports Polio Vaccine from Indonesia', Daily Trust (17 May 2004), pp. 1-2.

45 Professor Oyewale Tomori noted the importance of calling the programme Immunization Plus Days, rather than Polio Plus Days, which had been the name given to polio activities by Rotary International 
(Interview, 21 February 2008, Lagos). He was making the point that general immunisation efforts had been hampered by a focus on polio.

46 Centers for Disease Control and Prevention, 'Wild Poliovirus Weekly Update' (26 November 2008), www.polioeradication.org (accessed 28 November 2008).

47 Professor Pate has been a strong supporter of routine immunisation; R. Leo, 'Preventive Medicine is the Way to Go - Pate', Daily Trust (20 September 2011), www.dailytrust.com.ng, (accessed 20 September 2011).

48 National Primary Health Care Development Agency (NPHCDA), Nigeria, '17th Meeting of the Expert Review Committee (ERC) on Polio Eradication \& Routine Immunization in Nigeria' (Ota, Ogun State, 1-2 April 2009), www.polioeradication.org/Resourcelibrary/Advisoryandcertification/TechnicalAdvisoryGroups.aspx (accessed 25 November 2011).

49 National Primary Health Care Development Agency (NPHCDA), Nigeria, '16th Meeting of the Expert Review Committee (ERC) on Polio Eradication \& Routine Immunization in Nigeria' (Abuja, 27-28 October 2008). www.polioeradication.org/Resourcelibrary/Advisoryandcertification/TechnicalAdvisoryGroups.aspx (accessed 25 November 2011).

50 I. Mudashir, 'Sultan Constitutes Committee on Polio', Daily Trust (16 June 2009), p. 6; The head of the Shi'a community in Nigeria, Sheikh Ibrahim El-Zakzaky, cited Islamic approval of vaccination at an immunisation day exercise in Zaria in May 2008; A. Aodu and M. Abba, 'El-Zakzaky Advocates Immunisation Against Child Killer Diseases', Daily Trust (20 May), www.dailytrust.com.ng (accessed 22 May 2013).

51 Technical improvements in vaccines also increased immunisation effectiveness. Beginning in March 2006, the monovalent oral polio vaccine effective against the type 1 strain of the wild poliovirus was given to children in Nigeria, resulting in significant declines of type 1 poliovirus countrywide in 2009.

52 S. Taylor, 'Political Epidemiology: Strengthening Socio-Political Analysis for Mass Immunisation - Lessons from the Smallpox and Polio Programmes', Global Public Health, 4:6 (2009), p. 553.

53 MM, personal communication, 2012.

54 L. Adamu, 'Polio Returns with Menace in Kano', Daily Trust (5 November 2011), www.dailytrust.com.ng (accessed 5 November 2011).

55 Renne, Politics of Polio, pp. 42-5.

56 Interview: Professor H. A. Kaita, Ahmadu Bello University, Zaria (29 August 2005). 
57 Anonymous, DVD, Polio: Cuta ko Kariya? [Polio: Harm or Protection?] (Zaria: Darul Hadeeths Salafiyya, nd); W.H.O. Ta Ji Tsoro [WHO is Fearful] (Zaria: Darul Hadeeths Salafiyya, nd), purchased in Zaria in 2013.

58 See chapter 4, 'Islam and Immunization in Northern Nigeria', for a detailed discussion these views, Renne, Politics of Polio, pp. 51-67.

59 I. Al-Jawziyya, The Prophetic Medicine (Karachi: Hafiz and Sons, 2001). This book consists of a compilation of Hadith (sayings of the Prophet) and portions of the Qur'ān pertaining to illness which stresses the power of prayer in prevention and cure. Readers are told that for every disease, God created a cure - which may consist of prayer alone or may be combined with specific medicinal substances.

60 Anonymous, 'The Popular Discourses of Salafi Radicalism and Salafi Counter-Radicalism in Nigeria: A Case Study of Boko Haram', Journal of Religion in Africa, 42:2 (2012), p. 125.

61 National Population Commission, Nigeria, 2013 Nigeria Demographic Health Survey - Preliminary Report (Abuja, Nigeria: NPC, 2013), p. 25.

62 In January 2012, the Borno State government paid N100 million to the family of the Mohammad Yusuf in an out of court settlement; M. Olugbode, 'Borno Pays Deceased Boko Haram Leader's Family N100 Million', This Day (10 January 2012), http://allafrica.com/stories/201201100727 (accessed 14 January 2012).

63 D. McNeil, Jr, 'Gunmen Kill Nigerian Polio Vaccine Workers in Echo of Pakistan Attacks', New York Times (9 February 2013), p. A4; www.nytimes.com (accessed 9 Feb 2013).

64 L. Adamu and H. Yaya, 'Journalists Deny Inciting Attack on Polio Workers', Daily Trust (14 February 2013), www.dailytrust.com.ng (accessed 14 February 2013).

65 Sunday Trust, 'NBC Suspends Radio License', Sunday Trust (24 February 2013), www.sundaytrust.com (accessed 24 February 2013).

66 World Health Organization (WHO), Seventh Report - May 2013, Independent Monitoring Board of the Global Polio Eradication Initiative, Global Polio Eradication Initiative, www.polioeradication.org (accessed 6 June 2013).

67 I. Wakili, T. Hassan and H. Idris, 'President Declares State of Emergency ... Fighter Jets, Troops Moved to Borno, Yobe, Adamawa', Daily Trust (15 May 2013), http:/ / www.dailytrust.com.ng (accessed 15 May 2013).

68 IRIN, 'Nigeria: Jail Threat for Polio Vaccination Refuseniks' (11 August 2011), www.irinnews.org/Report/93480/NIGERIA-Jail-threat-for-poliovaccination refuseniks (accessed 1 May 2013).

69 The uncomfortable position of traditional leaders was exemplied by the Mai of Kaltungo's admission that parents in over 200 households 
in his domain had rejected polio vaccine; A. Hamagam, 'Niger Wins \$750,000 from Gates Foundation', Daily Trust (30 April 2013), www. dailytrust.com.ng (accessed 20 April 2013). Leonard discusses a similar dilemma in Chad where local political leaders must obey federal government orders while also respecting the concerns of local community members; L. Leonard, 'Working 'Off The Record”: Polio Eradication and State Immunity in Chad', Critical Public Health, 21 (2011), pp. 257-71.

70 S. Isuwa, 'LG Threatens Immunisation Defaulters with Legal Action', Daily Trust (8 July 2013), www.dailytrust.com.ng (accessed 8 July 2013).

71 Ibid.

72 Ibid.

73 World Health Organization (WHO), Seventh Report - May 2013, Independent Monitoring Board of the Global Polio Eradication Initiative.

74 This method of enticement backfired in Niger State when rumours that 'children could be initiated through petty offerings of sweets and biscuits' into secret cults, a practice called shafi milera. This situation ended this practice in the Niger State Immunization Plus program; R. Leo and J. L. Okafor, 'Weighty Effects of Birth Control on Polio Eradication', Daily Trust (10 July 2012), p. 51.

75 Interview: PO-09-1, Zaria, 27 June 2009.

76 S. Nasiru, G. Aliyu, A. Gasasira, M. Aliyu, M. Zubair, S. Mandawari, H. Waziri, A. Nasidi and S. El-Kamary, 'Breaking Community Barriers to Polio Vaccination in Northern Nigeria: The Impact of a Grass Roots Mobilization Campaign (Majigi)', Pathogens and Global Health, 106:3 (2012), pp. 166-71.

77 C. Alabi, 'Kaduna Engages Clerics in Fight Against Polio', Daily Trust (1 April 2013), p. 42.

78 For example, in 2013, Niger State 'won the award for recording an appreciable improvement in the campaign for the fight of polio eradication in the state'; Hamagam, 'Niger Wins \$750,000 from Gates Foundation'.

79 L. Danjuma, 'Polio: Dangote Rewards Immunised Families', Daily Trust (9 July 2013), www.dailytrust.com.ng (accessed 9 July 2013).

80 Interview: Professor Festus Adu, Ibadan, 22 February 2008.

81 Feilden Battersby Analysts (FBA), The State of Routine Immunization Services in Nigeria and Reasons for Current Problems. Bath: FBA Health Systems Analysts, 2005, www.technet21.org/backgrounddocs.html (accessed 15 August 2005); T. Omoniyi, 'Routine Immunization for Infants: Still a Battle Royale', Daily Trust (4 June 2012), www.dailytrust.com.ng (accessed 7 June 2012).

82 L. Adamu, 'Polio Returns with Menace in Kano'. 
83 The 12th Expert Review Committee reported routine stock outs; National Primary Health Care Development Agency (NPHCDA), Nigeria, '12th Meeting of the Expert Review Committee (ERC) on Polio Eradication \& Routine Immunization in Nigeria (Abuja, 3-4 May 2007), p. 8, www.polioeradication.org/Resourcelibrary/Advisoryandcertification/ TechnicalAdvisoryGroups.aspx (accessed 25 November 2011). During the federal and state elections in 2011, there were 'stock outs', with no vaccine availability in some health centres. Post-election violence in several northern Nigerian states also affected immunisation efforts.

84 According to a Nigerian National Bureau of Statistics report released in February 2012, poverty rates in northern Nigeria are estimated as having ranged from $76 \%$ to $86 \%$ in 2010; BBC, 'Nigerians Living in Poverty Rise to Nearly 61\%', BBC World News (13 February 2012), www.bbc.co.uk/ news/world-africa-17015873 (accessed 13 February 2012).

85 'Though located in a village whose residents are mostly farmers, petty traders and cattle rearers, the health centre, painted a bright yellow and green, had just been renovated and one would expect that the services provided should be at par with its physical outlook'; Adebayo, 'Vaccine Delivery, Still a Mirage in Nigeria.' See also A. Masquelier, 'Behind the Dispensary's Prosperous Facade: Imagining the State in Rural Niger', Public Culture, 13:2 (2011), pp. 267-91.

86 Ibid.; Adebayo, 'Vaccine Delivery, Still a Mirage in Nigeria'.

87 NPHCDA, '17th Meeting of the Expert Review Committee (ERC) on Polio Eradication \& Routine Immunization in Nigeria'.

88 National Primary Health Care Development Agency (NPHCDA), Nigeria, 'Final Report: 24th Meeting of the Expert Review Committee (ERC) On Polio Eradication \& Routine Immunization in Nigeria, 10-11 September 2012', www.polioeradication.org/Resourcelibrary/Advisoryandcertification/TechnicalAdvisoryGroups.aspx (accessed 26 August 2013).

89 GAVI Alliance, 'Annual Progress Report 2011', submitted by the Government of Nigeria (Geneva: GAVI Alliance, 2012), www.gavialliance.org/ country/nigeria/documents/\#apr (accessed 13 August 2013).

90 Tomori said, 'We should expect that there will be measles outbreak in 2013 because the government did not talk about it in 2012 ... The issue of which vaccine gets which funding has been politicized'; Adebayo, 'Vaccine Delivery, Still a Mirage in Nigeria'. Unfortunately, his predicted measles outbreak was correct as in March 2013, outbreaks occurred in several northern Nigerian states, with reports of 4,000 children having contracted the disease and thirty-six deaths. This outbreak occurred despite measles vaccination campaigns in late 2008 and reported high levels of measles immunity nationally in 2011. 
91 R. Leo, 'GAVI gives N3bn to Improve Vaccine Access', Daily Trust (13 August 2013), www.dailytrust.com.ng (accessed 13 August 2013).

92 Ekunjimi was referring specifically polio eradication initiative funding, saying that 'Corruption in the system will not allow a polio-free Nigeria by 2015'; T. Olusegun, 'The Resurgence of Polio in Nigeria', Inter Press Service (19 June 2012), www.globalissues.org/news/2012/06/19/14012 (accessed 16 August 2013).

93 H. Musa, 'Kwankwaso Fires Polio Officials Over Corruption', Daily Trust (8 October 2013), www.dailytrust.com.ng (accessed 8 October 2013).

94 J. Okafor, 'Polio: FG to Vaccinate 28m Children', Daily Trust (13 December 2012), www.dailytrust.com.ng (accessed 13 December 2013).

$95 \mathrm{He}$ is referring to the Nigerian president, Goodluck Jonathan (and to the Ebola virus).

96 Adebayo, 'Vaccine Delivery, Still a Mirage in Nigeria'.

97 Taylor, 'Political Epidemiology, p. 552.

98 WHO, 'WHO Removes Nigeria from Polio Endemic List', Global Polio Eradication website (25 September 2015), www.polioeradication.org (accessed 2 October 2015).

99 M. Vaughan, Curing their Ills: Colonial Power and African Illness (Cambridge: Polity Press, 1991).

100 Muraskin has observed a similar dynamic regarding the implementation of the GPEI in India; W. Muraskin, Polio Eradication and its Discontents (Hyderabad: Orient BlackSwan, 2012).

101 Lughod, 'Romance of Resistance'. 
Elisha P. Renne - 9781526110916

Downloaded from manchesterhive.com at $04 / 26 / 2023$ 04:45:54AM 